\title{
QUALITY - COST TRADE OFF (QCT) FOR CONTRACTOR SELECTION
}

\author{
Manish Kumar Sharma ${ }^{1}$, R. Kansal ${ }^{2}$ \\ ${ }^{1}$ Student M.E- CTM, Madhav institute of technology and science, Gwalior M.P, India \\ ${ }^{2}$ Prof and head civil dept, Madhav institute of technology and science, Gwalior M.P, India
}

\begin{abstract}
The construction industries has witnessed the failure of many projects led to the contractor selection. The various reasons of project failure concern contractor selection is financial problems, poor performance lack of adequate quality consideration at worksite. All these incidents is depend upon the current system of awarding the contractor in which only price is competitiveness. To achieve the best value for money, the tender evaluation should consider not only price, but also compliance with Client's requirement. A quality cost trade off (QCT) based contractor selection model is structured to cover non -price attributes i.e. quality together with the bid price. The (QCT) model enables the user to designate the weighting of non price and price criteria depending on the need and wants of the client and or project. The results show that the model provides a guide for the client to reward experienced, capable and qualified contractors, and eliminate incompetent, inexperienced for the success and quality of work.
\end{abstract}

Keywords - Tendering; Competitive bidding strategy; Contractor selection; *** $*$

\section{INTRODUCTION}

Traditionally the project is considered successful if delivered on time, within budget and quality. The concept of project success is directly depend upon the perception of participant i.e. the client, the architect and the contractor. From project to project participant have their own opinion of success. Contractor selection is very typical task because the contractor play a vital role for success of project. Executing the project as per client's requirement, evaluation of contractor and selection of best bidder requires a sophisticated knowledge and experience.

The traditional bidding method is based on the lowest tender price, in which the bidder have no idea about price of the competitive bidder, so he offers the lowest bid price to win the bid, compromising the quality. However, low price, product or services may not meet the quality requirement. Bid evaluation based on the lowest bid price is suitable in simple and small size projects, but it failure for complex and innovative work. Therefore contractor selection process based on quality consideration is required to improve the drawback of the traditional tendering method. This study aims to present a model for selecting the best bidder take into account the factor price and quality also.

\section{ESSENTIAL OF QUALITY IN CONTRACTOR SELECTION}

It is required to achieve objective in term of procurement outcome, quality criteria should be introduce into the evaluation of tender. Yet means of ensuring that only those tenders who are likely to deliver the required quality and compete for the award of a contract. Quality and cost directly proportional to the nature of work i.e. innovative project, complex project and simple project. If nature of work becomes more and more complex the procurement outcome become complex i.e.; the product and services with higher quality will be quoted higher price. Figure -1 indicate the relationship between price, quality and nature of work.

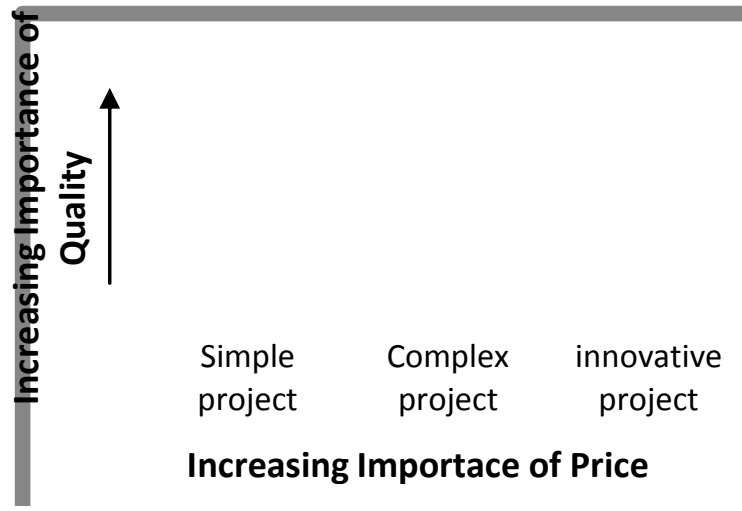

Fig. 1 Relationship between price, quality and nature of work

Quality criterion based on types of work possibly broken down into the sub-criteria to facilitate weightage to differed quality as per requirement of owner. According to CIDB, Pretoriya ,(1) and Turkish public procurement law (2) quality criteria and maximum score allocated to quality is considered and listed in Table -1 . The total weight of price and quality are equal to 100 percent . the scope of work define the weighting score of each, this weighting according to project type is as follows.

- $\quad$ Between 20/80 and 40/60 for innovative project

- Between 15/85 and 35/65 for complex project 
- $\quad$ Between 10/90 and 25/75 for simple project

- $\quad$ Between 05/95 and 10/90 for repetitive project
The maximum score for various evaluation criteria varies according to the nature of project, whether it is simple, complex or innovative and significance of the criteria for the project to be successful.

Table -1 Quality criteria and maximum score for bidder evaluation.

\begin{tabular}{|c|c|c|c|c|c|}
\hline \multirow[t]{2}{*}{ S.no } & \multirow[t]{2}{*}{$\begin{array}{l}\text { Evaluation } \\
\text { criteria }\end{array}$} & \multirow[t]{2}{*}{ Explanation } & \multicolumn{3}{|c|}{$\begin{array}{l}\text { Maximum score(out } \\
\text { of 10) for }\end{array}$} \\
\hline & & & $\begin{array}{l}\text { Innov } \\
\text { ative } \\
\text { project }\end{array}$ & $\begin{array}{l}\text { Com } \\
\text { plex } \\
\text { proje } \\
\text { ct }\end{array}$ & $\begin{array}{l}\text { Sim } \\
\text { ple } \\
\text { proj } \\
\text { ect }\end{array}$ \\
\hline 1 & $\begin{array}{l}\text { Methodology } \\
\text { and work plan } \\
\text { complete in } \\
\text { time frame }\end{array}$ & $\begin{array}{l}\text { Availability of an outline of quality } \\
\text { assurance / quality control } \\
\text { (QA/QC) programs, Availability of } \\
\text { ISO } 9000 \text { certification (or equivalent). }\end{array}$ & 5 & 4 & 2 \\
\hline 2 & $\begin{array}{l}\text { Organization } \\
\text { and staffing }\end{array}$ & $\begin{array}{l}\text { Availability of ISO } 9000 \text { certification } \\
\text { (or equivalent) or intention to Register, } \\
\text { Minimum period of trading under } \\
\text { same company name (attained } \\
\text { stability, reliability and accrued } \\
\text { experience) }\end{array}$ & 2 & 2.5 & 3 \\
\hline 3 & $\begin{array}{l}\text { Experience of } \\
\text { key staff }\end{array}$ & $\begin{array}{l}\text { Degree of education, experiences, } \\
\text { capabilities and competencies, skills } \\
\text { including professional and technical } \\
\text { expertise, and special } \\
\begin{array}{l}\text { Personnel qualifications of key } \\
\text { construction personnel }\end{array}\end{array}$ & 2 & 2.5 & 3 \\
\hline 4 & $\begin{array}{l}\text { Project } \\
\text { specific } \\
\text { performance }\end{array}$ & $\begin{array}{l}\text { By notices about past clients' levels of } \\
\text { satisfaction with the quality of } \\
\text { previous works by the contractor } \\
\text { (Architectural-aesthetics-structural } \\
\text { aspects; electrical-mechanical systems; } \\
\text { geotechnical and foundation aspects; } \\
\text { maintenance, reparation and technical } \\
\text { assistance etc) in the past years }\end{array}$ & 1 & 1 & 2 \\
\hline
\end{tabular}

\section{CASE STUDY}

The design build Innovative construction case is selected from the project of CWE at Gwalior for alteration of building estimated cost of Rs 50,78 lac. There are six contractor offering tender for the construction work and submitting quality information as per client's requirement with addition of their own bid price as shown in Table -2

Table 2

\begin{tabular}{|c|c|c|c|c|c|c|c|}
\hline \multirow[t]{2}{*}{ Evaluation criteria } & \multirow{2}{*}{$\begin{array}{l}\text { Maximum } \\
\text { score }(\text { out of 10) }\end{array}$} & \multicolumn{6}{|c|}{ Contractor id / relative score } \\
\hline & & $\mathbf{A}$ & B & $\mathbf{C}$ & $\mathbf{D}$ & $\mathbf{E}$ & $\mathbf{F}$ \\
\hline $\begin{array}{l}\text { Methodology and work plan } \\
\text { complete in time frame }\end{array}$ & 5 & 3.5 & 4 & 3.5 & 4 & 3.5 & 2.5 \\
\hline Organization and staffing & 2 & 1 & 1.2 & 1 & 1.4 & 1.4 & 1.2 \\
\hline Experience of key staff & 2 & 0.8 & 0.8 & 0.8 & 1.6 & 1.2 & 1.2 \\
\hline Project specific performance & 1 & 0.4 & 0.5 & 0.3 & 0.8 & 0.5 & 0.7 \\
\hline Total score & - & 5.7 & 6.5 & 5.6 & 7.8 & 6.6 & 5.6 \\
\hline Total maximum score & - & 10 & 10 & 10 & 10 & 10 & 10 \\
\hline Quality score percentage \% & - & 57 & 65 & 56 & 78 & 66 & 56 \\
\hline
\end{tabular}


Table -3 Ranking of contractor

\begin{tabular}{|l|l|l|l|l|l|l|}
\hline \multirow{2}{*}{$40 / 60$} & \multicolumn{6}{l}{ Contractor identification } \\
\cline { 2 - 7 } & $\mathrm{A}$ & $\mathrm{B}$ & $\mathrm{C}$ & $\mathrm{D}$ & $\mathrm{E}$ & $\mathrm{F}$ \\
\hline Quality score \% & 57 & 65 & 56 & 78 & 66 & 56 \\
\hline $\begin{array}{l}\text { Adjusted Quality score } \\
\%\end{array}$ & 73.07 & 83.33 & 71.79 & 100 & 84.61 & 71.79 \\
\hline $\begin{array}{l}\text { (a) Weighted Quality } \\
\text { score (40\%) }\end{array}$ & $\mathbf{2 9 . 2 2}$ & $\mathbf{3 3 . 3 3}$ & $\mathbf{2 8 . 7 1}$ & $\mathbf{4 0}$ & $\mathbf{3 3 . 8 4}$ & $\mathbf{2 8 . 7 1}$ \\
\hline Bid price & 55.25 & 54.9 & 54.8 & 53.9 & 52.1 & 49.06 \\
\hline Adjusted price score \% & 88.79 & 89.36 & 89.52 & 91.02 & 94.16 & 100 \\
\hline $\begin{array}{l}\text { (b) Weighted price } \\
\text { score (60\%) }\end{array}$ & $\mathbf{5 3 . 2 7}$ & $\mathbf{5 3 . 6 1}$ & $\mathbf{5 3 . 7 1}$ & $\mathbf{5 4 . 6 1}$ & $\mathbf{5 6 . 4 9}$ & $\mathbf{6 0}$ \\
\hline Total score (a + b) & $\mathbf{8 2 . 4 9}$ & $\mathbf{8 6 . 9 4}$ & $\mathbf{8 2 . 4 2}$ & $\mathbf{9 4 . 6 1}$ & $\mathbf{9 0 . 3 3}$ & $\mathbf{8 8 . 7 1}$ \\
\hline Ranking & 6 & 4 & 5 & $\mathbf{1}$ & 3 & 2 \\
\hline
\end{tabular}

Table -4 Ranking of contractor

\begin{tabular}{|c|c|c|c|c|c|c|}
\hline \multirow[t]{2}{*}{ 30/70 } & \multicolumn{6}{|c|}{ Contractor identification } \\
\hline & $\mathbf{A}$ & $\mathbf{B}$ & $\mathrm{C}$ & D & $\mathbf{E}$ & $\mathbf{F}$ \\
\hline Quality score \% & 57 & 65 & 56 & 78 & 66 & 56 \\
\hline $\begin{array}{l}\text { Adjusted } \quad \text { Quality } \\
\text { score } \%\end{array}$ & 73.07 & 83.33 & 71.79 & 100 & 84.61 & 71.79 \\
\hline $\begin{array}{lr}\text { (a) } & \text { Weighted } \\
\text { Quality } & \text { score } \\
(30 \%) & \\
\end{array}$ & 21.92 & 24.99 & 21.53 & 30 & 25.38 & 21.53 \\
\hline Bid price & 55.25 & 54.9 & 54.8 & 53.9 & 52.1 & 49.06 \\
\hline $\begin{array}{l}\text { Adjusted price score } \\
\%\end{array}$ & 88.79 & 89.36 & 89.52 & 91.02 & 94.16 & 100 \\
\hline $\begin{array}{l}\text { (b) Weighted price } \\
\text { score }(70 \%)\end{array}$ & 62.15 & 62.55 & 62.66 & 63.17 & 65.91 & 70 \\
\hline Total score $(a+b)$ & 84.07 & 87.54 & 84.19 & 93.71 & 91.29 & 91.53 \\
\hline Ranking & 6 & 4 & 5 & 1 & 3 & 2 \\
\hline
\end{tabular}

Table -5 Ranking of contractor

\begin{tabular}{|c|c|c|c|c|c|c|}
\hline \multirow[t]{2}{*}{$20 / 80$} & \multicolumn{6}{|c|}{ Contractor identification } \\
\hline & $\mathbf{A}$ & $\mathbf{B}$ & $\mathbf{C}$ & $\mathbf{D}$ & $\mathbf{E}$ & $\mathbf{F}$ \\
\hline Quality score \% & 57 & 65 & 56 & 78 & 66 & 56 \\
\hline $\begin{array}{l}\text { Adjusted } \\
\text { score } \%\end{array}$ & 73.07 & 83.33 & 71.79 & 100 & 84.61 & 71.79 \\
\hline $\begin{array}{lr}\text { (a) } & \text { Weighted } \\
\text { Quality } & \text { score } \\
(\mathbf{3 0 \%}) & \\
\end{array}$ & 14.61 & 16.66 & 14.35 & 20 & 16.92 & 14.35 \\
\hline Bid price & 55.25 & 54.9 & 54.8 & 53.9 & 52.1 & 49.06 \\
\hline $\begin{array}{l}\text { Adjusted price score } \\
\%\end{array}$ & 88.79 & 89.36 & 89.52 & 91.02 & 94.16 & 100 \\
\hline $\begin{array}{l}\text { (b) Weighted price } \\
\text { score }(70 \%)\end{array}$ & 71.03 & 71.48 & 71.61 & 72.81 & 75.32 & 80 \\
\hline Total score $(\mathbf{a}+\mathbf{b})$ & 85.64 & 88.41 & 85.51 & 92.81 & 92.24 & 94.35 \\
\hline Ranking & 5 & 4 & 6 & 2 & 3 & 1 \\
\hline
\end{tabular}

The result of Table 3, 4 and 5 are compiled and shown in Table 6. It indicate the change in ranking of contractor with change in the weightage of quality and price consideration 
Table -6: Contractor Ranking

\begin{tabular}{|l|l|l|l|l|l|l|}
\hline \multirow{2}{*}{$\begin{array}{l}\text { Weightage } \\
\text { Quality/ price ratio }\end{array}$} & \multicolumn{2}{|l|}{ Contractor ranking } & B & \multicolumn{4}{l|}{$\mid$} \\
\cline { 2 - 8 } & A & B & C & D & E & F \\
\hline Bid Price- Price (100\%) & 6 & 5 & 4 & 3 & 2 & $\mathbf{1}$ \\
\hline Quality (20\%) / Price (80\%) & 5 & 4 & 6 & 2 & 3 & $\mathbf{1}$ \\
\hline Quality (30\%) / Price (70\%) & 6 & 4 & 5 & $\mathbf{1}$ & 3 & 2 \\
\hline Quality (40\%)/ Price (60\%) & 6 & 4 & 5 & $\mathbf{1}$ & 3 & 2 \\
\hline
\end{tabular}

\section{CONCLUSION}

As per table 6 which shows the result for the data of a particular project, contractor ranking changes with change in quality and price weightage. Contractor $\mathrm{F}$ is ranked no. 1 if there is no consideration of quality and also in case if $20 \%$ weightage is given to quality. However contractor D become no. 1 if the weightage of quality increase $30 \%$ and more. It is helpful in selection of contractor according to the weightage to be given to quality.

\section{REFERENCES}

[1] Best Practice Guideline A4: Evaluating Quality in Tender Submission. Edn. 2. CIDB Document 1004. Aug 2006.

[2] Aysegul Yilmaz, Sema Ergonul: Selection of Contractors for Middle-SizedProjects in Turkey,GU J Sci, 24(3):477-485 (2011)

[3] Abdelrahman M, Zayed T, Elyamany A. Best-Value Model Based on Project Specific Characteristics. J. Constr. Eng. Manage. 2008; 134(3): 179-188p.

[4] Akintoye A, Hardcastle C, Beck M, et al. Achieving Best Value in Private Finance Initiative Project Procurement. Constr. Manage. Econ. 2003; 21(5): 461-470p.

[5] Gransberg DD, Ellicott MA. Best-Value Contracting Criteria. Cost Eng. 1997; 39(6): 31-34p.

[6] Griffis FH. Bidding Strategy: Winning Over Key Competitors. J. Constr. Eng. Manage. 1992; 118(1): 151-165p.

[7] Hatush, Z, Skitmore, M. "Criteria for contractor selection" Construction Management and Economics, 15, 19-38 (1997a).

[8] PPL 4734. Turkish Public Procurement Law (2003)

[9] Wong, C.H., Holt, G.D. and Cooper, P.A. "Lowest price or value? Investigation of UK construction clients' tender selection process" Construction Management and Economics, 18, 767-774 (2000). 